\title{
Synthesis and electrochemical behavior of the ferrocenyl units assembled on imidoalane and carbaalane clusters
}

\author{
S. Shravan Kumar ${ }^{\text {a }}$, Herbert W. Roesky ${ }^{\text {a,* }}$, Ovidiu Andronesi ${ }^{\text {b, }}$ \\ Marc Baldus ${ }^{b}$, Rainer F. Winter ${ }^{\mathrm{c}}$ \\ a Institut für Anorganische Chemie der Universität Göttingen, Tammannstrasse 4, D 37077 Göttingen, Germany \\ ${ }^{\mathrm{b}}$ Max Planck Institut für Biophysikalische Chemie, D 37077 Göttingen, Germany \\ ${ }^{\mathrm{c}}$ Institut für Anorganische Chemie der Universität Stuttgart. Pfaffenwaldring 55, D 70569 Stuttgart, Germany
}

\begin{abstract}
Hydroalumination reaction was effectively carried out on ferrocenylnitrile in the synthesis of imidoalane cluster [HAl $\left.\mathrm{NCH}_{2} \mathrm{C}_{5} \mathrm{H}_{4} \mathrm{FeCp}\right]_{6}$ (3). Compound 3 exhibits a reversible electrochemical behavior. In the presence of ferrocenylmethanol, meta thesis reactions were carried out on $\left[\mathrm{HAlNCH}_{2}\left(\mathrm{C}_{4} \mathrm{H}_{3} \mathrm{~S}\right)\right]_{6}(4)$ and $\left[\mathrm{HAlNCH}_{2} \mathrm{Ph}\right]_{6}$ (5) in the synthesis of $\left[\mathrm{CpFeC}_{5} \mathrm{H}_{4}\right.$ $\left.\mathrm{CH}_{2} \mathrm{OAINCH}_{2}\left(\mathrm{C}_{4} \mathrm{H}_{3} \mathrm{~S}\right)\right]_{6}(6)$ and $\left[\mathrm{CpFeC}_{5} \mathrm{H}_{4} \mathrm{CH}_{2} \mathrm{OAlNCH}_{2} \mathrm{Ph}\right]_{6}$ (7). The ferrocenylmethoxide groups present in these two com pounds show a single reversible oxidation wave, which suggests their electrochemical equivalence. Electrochemical studies were also carried out on the carbaalane $\left[(\mathrm{AlH})_{2}(\mathrm{FcC} \quad \mathrm{CAl})_{4}\left(\mathrm{AlNMe}_{3}\right)_{2}\left(\mathrm{CCH}_{2} \mathrm{Ph}\right)_{6}\right](9)$, which exhibited a considerably broadened wave with shoulders preceding the main anodic and cathodic peak, and it can be assigned to weak electronic interactions between the individ ual ferrocenyl sites.
\end{abstract}

Keywords: Hydroalumination; Imidoalane; Carbaalane; Ferrocene; Electrochemistry

\section{Introduction}

Compounds containing multi-metallocenyl assemblies, especially multi-ferrocenyl assemblies [1,2], have gained importance in recent years due to their interesting chemical, electrical, optical and magnetic properties. These compounds are electron-rich in nature and they can be considered as efficient materials for the modification of electrodes, ion sensors or as material for the electronic devices [3 5]. Although, most of the work was done to understand the redox nature of the ferrocene containing dendrimers [6 9 9] only recently transition me-

\footnotetext{
${ }^{*}$ Corresponding author. Tel.: +49 551 393001/45; fax: +49 55 393373.

E mail address: hroesky@gwdg.de (H.W. Roesky).
}

tal containing main group compounds have gained attention as they are single source precursor for mixed-metal thin films [10,11]. Recently, we have reported for the first time the synthesis and structure of imidoalane cluster $\left[\mathrm{CpFeC}_{5} \mathrm{H}_{4} \mathrm{C} \equiv \mathrm{CAINCH}_{2}\left(\mathrm{C}_{4} \mathrm{H}_{3} \mathrm{~S}\right)\right]_{6}$ (1) containing an assembly of ferrocenylacetylide units [12]. The ferrocenyl units, which are fixed on the cluster using $\mathrm{C} \equiv \mathrm{C}$ spacers, showed a reversible electrochemical behavior with a half wave oxidation potential of $+0.16 \mathrm{~V}$. Subsequently, we reported a carbaalane [(Al$\left.\mathrm{H})_{6}\left(\mathrm{AlNMe}_{3}\right)_{2}\left(\mathrm{CCH}_{2} \mathrm{C}_{5} \mathrm{H}_{4} \mathrm{FeC}_{5} \mathrm{H}_{5}\right)_{6}\right] \quad$ (2) containing ferrocenylmethylene units and an attempt to study the electrochemical behavior of the carbaalane was unsuccessful due to its poor solubility [13]. These two compounds are the model compounds for the fixation of an organometallic fragment on an aluminum nitride 
and carbide surface. In continuation of the above mentioned work, herein we report the synthesis and electrochemical behavior of a few more imidoalane and carbaalane clusters containing ferrocene units.

\section{Experimental}

\subsection{Materials and equipment}

All experimental manipulations were carried out under an atmosphere of dry nitrogen using standard Schlenk techniques. The samples for spectral measurements were prepared in a dry box. Solvents were purified according to conventional procedures and were freshly distilled prior to use. Compounds 4 [14,15], 5 $[16,17], 8$ [13,18], ferrocenylnitrile [19], ferrocenylacetylene $[20,21]$ and $\mathrm{AlH}_{3} \cdot \mathrm{NMe}_{3}$ [22] were prepared as described in the literature. IR spectra were recorded on a Bio-Rad Digilab FTS7 spectrometer. Melting points were obtained on a HWS-SG 3000 apparatus and are uncorrected. CHN analyses were performed at analytisches Labor des Instituts für Anorganische Chemie der Universität Göttingen, Germany. Solid state NMR for the nuclei ${ }^{1} \mathrm{H}$ and ${ }^{13} \mathrm{C}$ were recorded on Bruker Avance DMX at $600 \mathrm{MHz}$ proton frequency. The electrochemical experiments were performed at the Institut für Anorganische Chemie der Universität Stuttgart, Stuttgart, Germany. Cyclic voltammetric investigations on compounds 3, 6, 7, and 9 were conducted in $\mathrm{CH}_{2} \mathrm{Cl}_{2} /$ $\mathrm{Bu}_{4} \mathrm{NPF}_{6}(0.2 \mathrm{M})$ at ambient temperature; compound 9 was also studied in $\mathrm{THF} / \mathrm{Bu}_{4} \mathrm{NPF}_{6}(0.2 \mathrm{M})$. The electrochemical experiments were performed in a homebuilt cylindrical vacuum tight one compartment cell. A spiral shaped $\mathrm{Pt}$ wire and a $\mathrm{Ag}$ wire as the counter and reference electrodes are sealed directly into opposite sides of the glass wall, while the respective working electrodes (Pt or glassy carbon $1.1 \mathrm{~mm}$ polished with $0.25 \mu \mathrm{m}$ diamond paste (Buehler Wirtz) before each experiment series) are introduced via a teflon screw cap with a suitable fitting. The cell may be attached to a conventional Schlenk line via two sidearms equipped with teflon screw valves. $\mathrm{CH}_{2} \mathrm{Cl}_{2}$ and THF were obtained from Fluka (Burdick\&Jackson Brand) and freshly distilled from $\mathrm{CaH}_{2}\left(\mathrm{CH}_{2} \mathrm{Cl}_{2}\right)$ or $\mathrm{Na}$ (THF) before use. $\mathrm{Bu}_{4} \mathrm{NPF}_{6}$ was used as the supporting electrolyte. All compounds are oxidized at nearly the same potential as ferrocene such that decamethylferrocene had to be employed as the internal standard for potential calibration. Referencing against the ferrocene/ferrocenium scale was then performed by determining the half-wave potential of decamethylferrocene $\left(E_{1 / 2}=-0.55 \mathrm{~V}\right)$ against the ferrocene/ferrocenium standard in a separate set of experiments but under otherwise identical conditions and recalculating the observed $E_{1 / 2}$ values of the respective analyte relative to the ferrocene/ferrocenium scale. Assessment of the individual half-wave potentials of 9 was performed as follows: first, the experimental wave of the ferrocene couple was simulated. Values of $D\left(2.40 \mathrm{~cm}^{2} \mathrm{~s}^{-1}\right)^{52}, k_{\mathrm{s}}$ $\left(6.8 \times 10^{6} \mathrm{~cm} \times \mathrm{s}^{-1}\right)$ and $\alpha(0.49)$ were taken from the literature [22]. Ohmic drop was included such that the experimental peak-to-peak separation of the $\mathrm{Cp}_{2} \mathrm{Fe}^{0 /+}$ couple was reproduced over a range of sweep rates ranging from $v=0.051 \mathrm{~V} / \mathrm{s}$. Next, the wave of the analyte was analyzed by adjusting the individual $E_{1 / 2}$ values until good agreement between simulated and experimental CVs was obtained over the entire range of sweep rates. Digital simulations of experimental CVs were performed with DigiSim ${ }^{\circledR}$ (version 3.0a) available from BAS.

\subsection{Synthesis}

\subsubsection{Synthesis of $\left[\mathrm{HAlNCH}{ }_{2} \mathrm{C}_{5} \mathrm{H}_{4} \mathrm{FeCp}\right]_{6}$ (3)}

$\mathrm{AlH}_{3} \cdot \mathrm{NMe}_{3}(10 \mathrm{~mL}, 0.5 \mathrm{M}$ solution in toluene) was added to a solution of ferrocenylnitrile (1.50 g, $13.74 \mathrm{mmol})$ in toluene $(30 \mathrm{~mL})$ under stirring at room temperature. The reaction mixture was heated until the evolution of $\mathrm{NMe}_{3}$ had ceased. The resultant solution was cooled and upon removal of solvent orange red colored compound 3 was obtained (1.25 g, yield 73\%). M.p: $>300^{\circ} \mathrm{C}$ (decomp.). IR ( $\left.\mathrm{KBr}, \mathrm{Nujol}\right): v=1845$ (br, $\mathrm{Al}$ H), 1560 (w), 1261 (m), $1230(\mathrm{~m}), 1105$ (m), 1024 (w), 898 (w), 802 (w), $722(w), 701(\mathrm{~m}), 481(\mathrm{~s}) \mathrm{cm}^{-1} .{ }^{1} \mathrm{H}$ NMR $(600 \mathrm{MHz}, 25 \mathrm{KHz}, \mathrm{MAS}): \delta=2.8(\mathrm{~s}, 12 \mathrm{H}$, $\left.\mathrm{NCH}_{2}\right), 4.3$ (br, $54 \mathrm{H}, \mathrm{C}_{5} \mathrm{H}_{4} \mathrm{FeCp}$ ) ppm. ${ }^{13} \mathrm{C} \mathrm{NMR}$ (600 MHz, $25 \mathrm{KHz}$, MAS): $\delta=42.0\left(\mathrm{NCH}_{2}\right), 68.0$ $\left(\mathrm{C}_{5} \mathrm{H}_{4} \mathrm{FeCp}\right) \mathrm{ppm}$. In the mass spectrum, only small fragments were found. Anal. Calc. for $\mathrm{C}_{66} \mathrm{H}_{72} \mathrm{Al}_{6} \mathrm{~N}_{6} \mathrm{Fe}_{6}$ : C, 54.81; H, 5.02; N, 5.81. Found: C, 55.21; H, 5.65; N, $6.27 \%$.

\subsubsection{Synthesis of $\left[\mathrm{CpFeC}_{5} \mathrm{H}_{4} \mathrm{CH}_{2} \mathrm{OAlNCH}_{2}\left(\mathrm{C}_{4} \mathrm{H}_{3} \mathrm{~S}\right)\right]_{6}$ (6)}

To a suspension of $4(0.24 \mathrm{~g}, 0.29 \mathrm{mmol})$ in toluene $(30 \mathrm{~mL})$ was added ferrocenylmethanol $(0.38 \mathrm{~g}$, $1.77 \mathrm{mmol}$ ) at room temperature. The reaction mixture was stirred for an hour at room temperature before heating it until the evolution of $\mathrm{H}_{2}$ had ceased. The resultant solution was cooled and upon removal of the solvent orange red colored compound $\mathbf{6}$ was obtained $(0.41 \mathrm{~g}$, yield $68 \%$ with respect to 4$)$. M.p: $>300{ }^{\circ} \mathrm{C}$ (decomp.). IR (KBr, Nujol): $v=1637$ (w), $1261(\mathrm{~m}), 1230$ (w), 1105 (w), 1021 (w), 923 (w), 815 (m), $694(\mathrm{~m}) \mathrm{cm}^{-1}$. ${ }^{1} \mathrm{H}$ NMR $(600 \mathrm{MHz}, 25 \mathrm{KHz}, \mathrm{MAS}): \delta=2.4(\mathrm{~s}, 12 \mathrm{H}$, $\mathrm{NCH}_{2}$ ), 3.6 (s, 12H, OCH $\mathrm{H}_{2}$, 4.1 (br, $54 \mathrm{H}, \mathrm{C}_{5} \mathrm{H}_{4} \mathrm{FeCp}$ ), 6.87 .3 (br, $\left.18 \mathrm{H}, \mathrm{C}_{4} \mathrm{H}_{3} \mathrm{~S}\right) \mathrm{ppm} .{ }^{13} \mathrm{C}$ NMR $(600 \mathrm{MHz}$, $25 \mathrm{KHz}, \mathrm{MAS}): \delta=42.0\left(\mathrm{NCH}_{2}\right), 59.0\left(\mathrm{OCH}_{2}\right), 67.0$ $\left(\mathrm{C}_{5} \mathrm{H}_{4} \mathrm{FeCp}\right), 124.0127 .0\left(\mathrm{C}_{4} \mathrm{H}_{3} \mathrm{~S}\right) \mathrm{ppm}$. In the mass spectrum, only small fragments were found. Anal. Calc. 
for $\mathrm{C}_{96} \mathrm{H}_{96} \mathrm{Al}_{6} \mathrm{Fe}_{6} \mathrm{~N}_{6} \mathrm{O}_{6} \mathrm{~S}_{6}: \mathrm{C}, 54.47 ; \mathrm{H}, 4.57 ; \mathrm{N}, 3.97$. Found: C, 55.83; H, 4.68; N, 4.26\%.

\subsubsection{Synthesis of $\left[\mathrm{CpFeC}_{5} \mathrm{H}_{4} \mathrm{CH}_{2} \mathrm{OAlNCH}_{2} \mathrm{Ph}\right]_{6}$ (7)}

To a suspension of $5(0.50 \mathrm{~g}, 0.63 \mathrm{mmol})$ in toluene $(30 \mathrm{~mL})$ was added ferrocenylmethanol $(0.84 \mathrm{~g}$, $3.88 \mathrm{mmol}$ ) at room temperature. The reaction mixture was stirred for an hour at room temperature before heating it until the evolution of $\mathrm{H}_{2}$ had ceased. The resultant solution was cooled and upon removal of the solvent orange red colored compound 7 was obtained ( $1.33 \mathrm{~g}$, yield $74 \%$ with respect to 5 ). M.p: $>300{ }^{\circ} \mathrm{C}$ (decomp.). IR (KBr, Nujol): $v=1604$ (w), 1263 (m), 1230 (w), $1105(w), 1024(w), 808(w), 701(\mathrm{~m}) \mathrm{cm}^{-1} \cdot{ }^{1} \mathrm{H}$ NMR $(600 \mathrm{MHz}, 25 \mathrm{KHz}, \mathrm{MAS}): \delta=3.1$ (s, $12 \mathrm{H}$, $\mathrm{NCH}_{2}$ ), 3.3 (s, $12 \mathrm{H}, \mathrm{OCH}_{2}$ ), 4.1 (br, $54 \mathrm{H}, \mathrm{C}_{5} \mathrm{H}_{4} \mathrm{FeCp}$ ), 6.67 .2 (br, $\left.30 \mathrm{H}, \mathrm{C}_{6} \mathrm{H}_{5}\right)$ ppm. ${ }^{13} \mathrm{C} \mathrm{NMR}(600 \mathrm{MHz}$, $25 \mathrm{KHz}, \mathrm{MAS}): \delta=42.0\left(\mathrm{NCH}_{2}\right), 60.0\left(\mathrm{OCH}_{2}\right), 68.0$ $\left(\mathrm{C}_{5} \mathrm{H}_{4} \mathrm{FeCp}\right), 125.0130 .0\left(\mathrm{C}_{6} \mathrm{H}_{5}\right) \mathrm{ppm}$. In the mass spectrum, only small fragments were found. Anal. Calc. for $\mathrm{C}_{108} \mathrm{H}_{108} \mathrm{Al}_{6} \mathrm{Fe}_{6} \mathrm{~N}_{6} \mathrm{O}_{6}: \mathrm{C}, 62.27 ; \mathrm{H}, 5.23 ; \mathrm{N}, 4.03$. Found: C, $62.58 ; \mathrm{H}, 5.77 ; \mathrm{N}, 4.49 \%$.

\section{Results and discussion}

To a toluene solution of ferrocenylnitrile was added an excess of $\mathrm{AlH}_{3} \cdot \mathrm{NMe}_{3}$ at room temperature. The reaction mixture was stirred at ambient temperature for $0.5 \mathrm{~h}$ and heating the resultant solution till the evolution of $\mathrm{NMe}_{3}$ had ceased gave $\left[\mathrm{HAlNCH}_{2} \mathrm{C}_{5} \mathrm{H}_{4}-\right.$ $\mathrm{FeCp}_{6}$ (3) in good yield (Scheme 1). The experimental conditions employed in the synthesis of $\left[\mathrm{CpFeC}_{5} \mathrm{H}_{4}\right.$ $\left.\mathrm{CH}_{2} \mathrm{OAlNCH}_{2}\left(\mathrm{C}_{4} \mathrm{H}_{3} \mathrm{~S}\right)\right]_{6}$ (6) and $\left[\mathrm{CpFeC}_{5} \mathrm{H}_{4} \mathrm{CH}_{2} \mathrm{OA}\right.$ $\left.1 \mathrm{NCH}_{2} \mathrm{Ph}\right]_{6}(7)$ are similar to that of compound 1 . The reaction between stoichiometric amount of ferrocenylmethanol and $\left[\mathrm{HAINCH}_{2}\left(\mathrm{C}_{4} \mathrm{H}_{3} \mathrm{~S}\right)\right]_{6}(4)$, ferrocenylmethanol and $\left[\mathrm{HAlNCH}_{2} \mathrm{Ph}\right]_{6}$ (5) under refluxing toluene conditions yielded compounds 6 and 7 in quantitative yield (Scheme 2). The synthetic details and the spectral data for the compound $\left[(\mathrm{AlH})_{2}(\mathrm{FcC} \equiv \mathrm{CAl})_{4}(\mathrm{AlN}\right.$ $\left.\left.\mathrm{Me}_{3}\right)_{2}\left(\mathrm{CCH}_{2} \mathrm{Ph}\right)_{6}\right](9)$ were described in our earlier work (Scheme 3) [13]. All the compounds were completely analyzed by means of spectral and elemental analyses. Compound 3 exhibits a characteristic broad stretching frequency corresponding to $\mathrm{Al} \mathrm{H}$ bond at $1845 \mathrm{~cm}^{-1}$
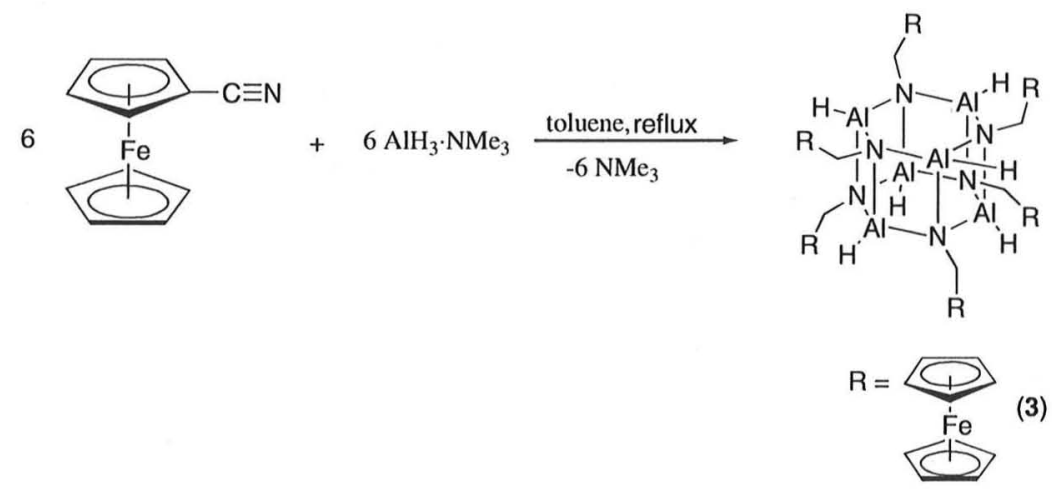

Scheme 1.
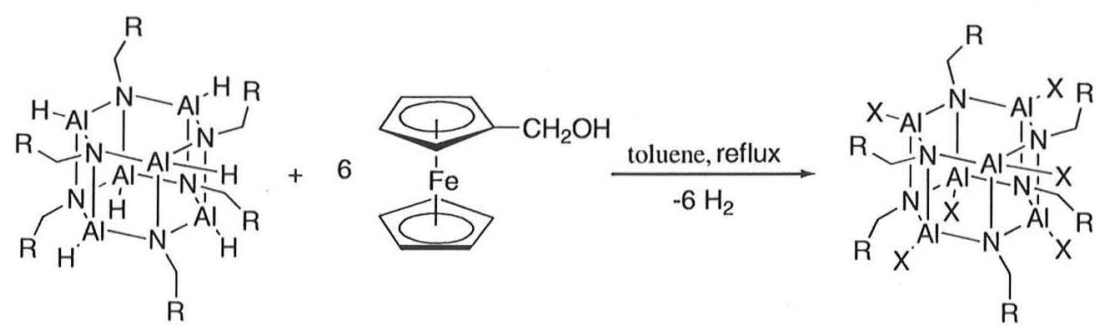

$$
\begin{aligned}
& \mathrm{R}=2-\mathrm{C}_{4} \mathrm{H}_{3} \mathrm{~S}(4) \\
& \mathrm{R}=\mathrm{Ph}(5)
\end{aligned}
$$

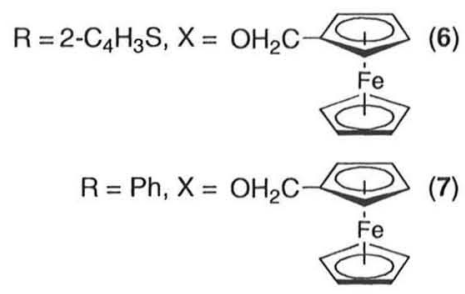




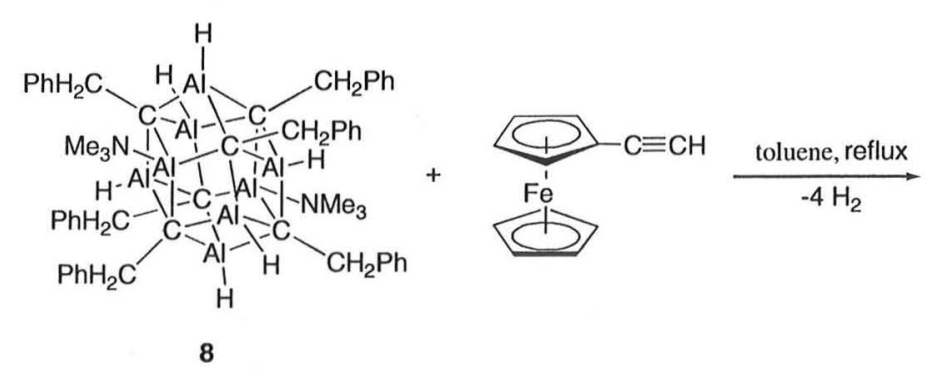

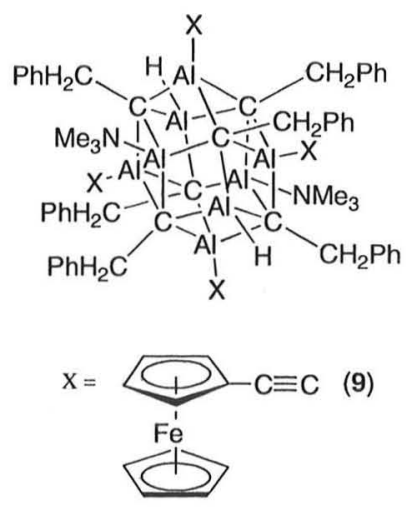

Scheme 3.

in the IR spectrum, which is absent in compounds 6 and 7. Although the compounds have very good solubility in aromatic solvents, we carried out solid-state NMR studies to have an uniformity in the spectral data for all the imidoalane and carbaalane clusters 3, 6, 7, and 9, respectively. The solid-state ${ }^{1} \mathrm{H}$ NMR for the protons of the ferrocenyl units appear at $\delta 4.3$ for 3 and at $\delta$ 4.1 for 6 and 7. The protons of $\mathrm{OCH}_{2}$ units in 6 and 7 resonate in the downfield region ( $\delta 3.6$ and $\delta 3.3)$, whereas singlets were observed for $\mathrm{NCH}_{2}$ protons in the upfield region ( $\delta 2.4$ for 6 and $\delta 3.1$ for 7 ). In the solid-state ${ }^{13} \mathrm{C}$ NMR spectra, the carbon atoms of the ferrocenyl units resonate at $\delta 68.0,67.0$, and 68.0, respectively, for 3, 6, and 7 and the carbon atoms of the $\mathrm{OCH}_{2}$ unit in 6 and 7 appear at $\delta 59.0$ and $\delta 60.0$. The resolution of the spectra in ${ }^{1} \mathrm{H}{ }^{13} \mathrm{C}$ 2D HETCOR (Heteroatom Correlation Spectra) showed this observation more clearly.

All compounds in this study are chemically and electrochemically reversible and oxidized at nearly the same potential like the ferrocene/ferrocenium standard. In compounds 3, 6 and 7, the oxidation of the individual ferrocene sites gives rise to only a single wave with basically the same characteristics like that of the internal Nernstian decamethylferrocene standard. Thus, the measured peak widths at half height, $\Delta E_{\mathrm{p} / 2}$, for the anodic (forward) peak and peak potential differences, $\Delta E_{\mathrm{p}}$ are just a few $\mathrm{mV}$ larger than the values measured for decamethylferrocene present at concentrations that rendered similar peak currents like that of the analyte. The same holds for differential pulse voltammetry. These signals at any interactions between the individual ferrocene entities are, at best, very weak. In these compounds, the ferrocenyl substituents are attached to the imidoalane cores through insulating methylene $\left(\mathrm{CH}_{2}\right)$ or methyleneoxy $\left(\mathrm{OCH}_{2}\right)$ spacers which interrupts any interactions between them. All data are compiled in Table 1 and Figs. 13 display the voltammogramms of the individual compounds at a scan rate of $50 \mathrm{mV} / \mathrm{s}$.
Table 1

Electrochemical data of compounds 3, 6, 7, and 9

\begin{tabular}{llcl}
\hline Compound & $E_{1 / 2}(\mathrm{~V})^{\mathrm{a}}$ & $\Delta E_{\mathrm{p}}(\mathrm{mV})^{\mathrm{b}}$ & $E_{\mathrm{p} / 2}(\mathrm{mV})^{\mathrm{b}}$ \\
\hline 3 & -0.010 & 64 & 63 \\
6 & -0.010 & 66 & 63 \\
7 & -0.025 & 62 & 60 \\
9 & $0.010,-0.060$ & 100 & 92 \\
\hline
\end{tabular}

${ }^{a}$ Half wave potentials are referenced versus the ferrocene/ferroce nium standard.

$\mathrm{b}$ The experimental values of decamethylferrocene were set equal to the theoretical value of $59 \mathrm{mV}\left(\Delta E_{\mathrm{p}}\right)$ or $57 \mathrm{mV}\left(E_{\mathrm{p} / 2}\right)$ [23] to account for Ohmic drop.

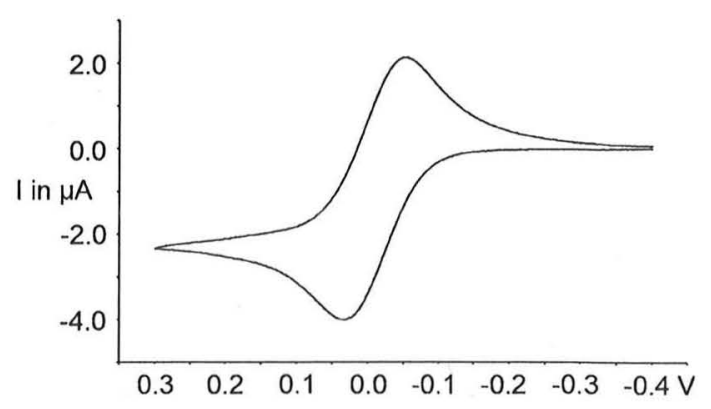

Fig. 1. Cyclic voltammogram of compound 3 in $\mathrm{CH}_{2} \mathrm{Cl}_{2} / \mathrm{Bu}_{4} \mathrm{NPF}_{6}$ $(0.2 \mathrm{M})$ at $v=0.05 \mathrm{~V} / \mathrm{s}$.

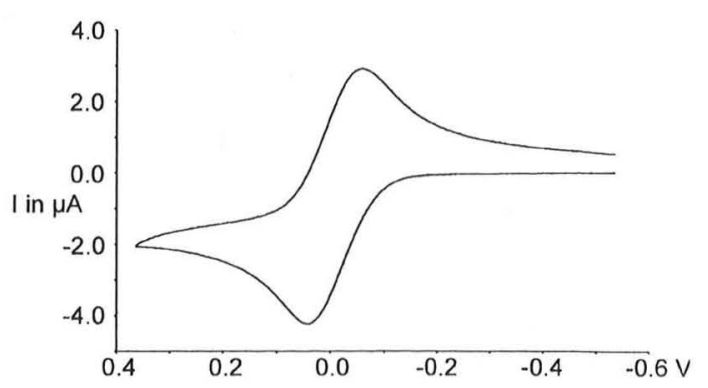

Fig. 2. Cyclic voltammogram of compound 6 in $\mathrm{CH}_{2} \mathrm{Cl}_{2} / \mathrm{Bu}_{4} \mathrm{NPF}_{6}$ $(0.2 \mathrm{M})$ at $v=0.1 \mathrm{~V} / \mathrm{s}$. 


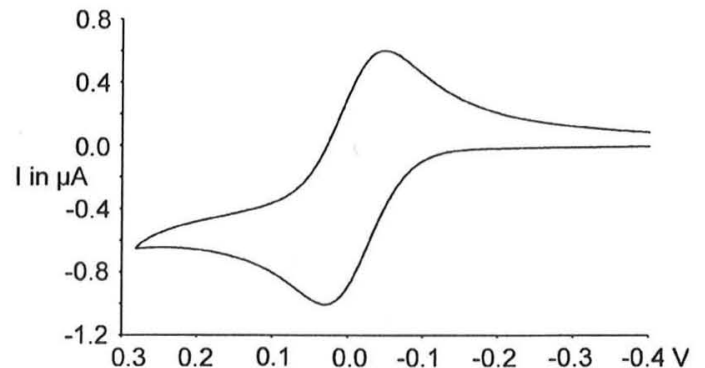

Fig. 3. Cyclic voltammogram of compound 7 in $\mathrm{CH}_{2} \mathrm{Cl}_{2} / \mathrm{Bu}_{4} \mathrm{NPF}_{6}$ $(0.2 \mathrm{M})$ at $v=0.05 \mathrm{~V} / \mathrm{s}$.

The one exception is complex 9 which exhibits a considerably broadened wave with shoulders preceding the main anodic and cathodic peak (Fig. 4(a) and (b)). The $\Delta E_{\mathrm{p} / 2}$ and $\Delta E_{\mathrm{p}}$ values are distinctly larger than those of the decamethylferrocene standard at all sweep rates. Figs. 5 and 6 display a typical voltammogram

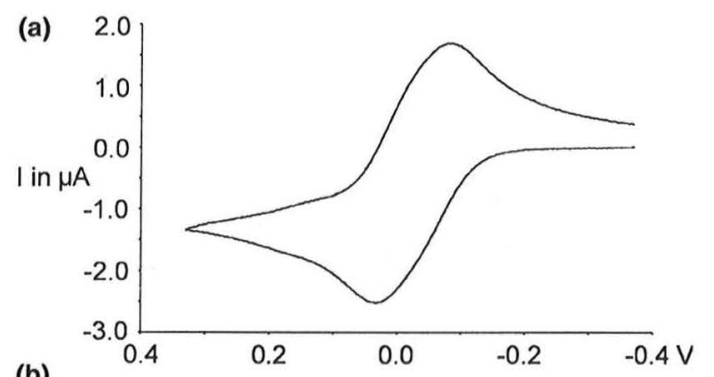

(b)

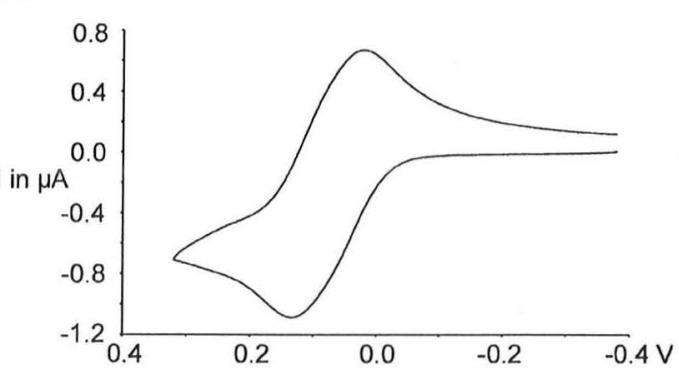

Fig. 4. (a) Cyclic voltammogram of compound 9 in $\mathrm{CH}_{2} \mathrm{Cl}_{2} / \mathrm{Bu}_{4} \mathrm{NPF}_{6}$ $(0.2 \mathrm{M})$ at $v=0.05 \mathrm{~V} / \mathrm{s}$. (b) Cyclic voltammogram of compound 9 in $\mathrm{THF} / \mathrm{Bu}_{4} \mathrm{NPF}_{6}(0.2 \mathrm{M})$ at $v=0.05 \mathrm{~V} / \mathrm{s}$.

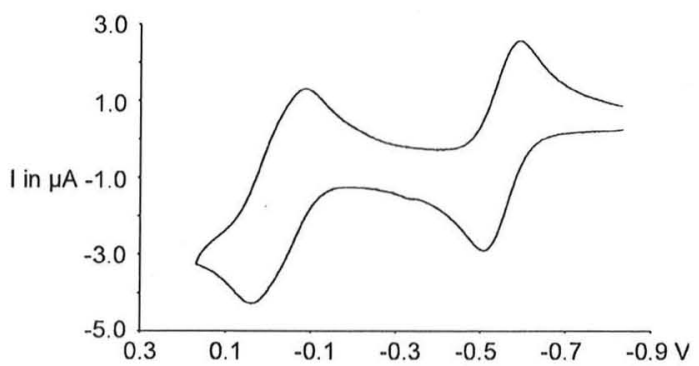

Fig. 5. Cyclic voltammogram of compound 9 in $\mathrm{CH}_{2} \mathrm{Cl}_{2} / \mathrm{Bu}_{4} \mathrm{NPF}_{6}$ $(0.2 \mathrm{M})$ in the presence of internal decamethylferrocene at $v=0.05 \mathrm{~V} / \mathrm{s}$.

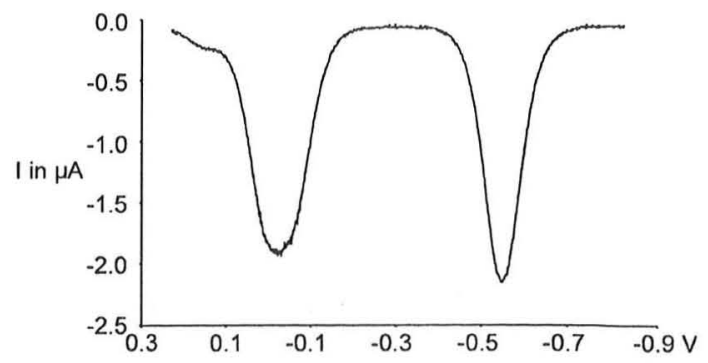

Fig. 6. Differential pulse voltammogram of 9 at $v=5 \mathrm{mV} / \mathrm{s}$ in $\mathrm{CH}_{2} \mathrm{Cl}_{2} /$ $\mathrm{Bu}_{4} \mathrm{NPF}_{6}(0.2 \mathrm{M})$ in the presence of internal decamethylferrocene.

and a differential pulse voltammogram of 9 in the presence of decamethylferrocene which clearly shows the broadening. Essentially, the same results were obtained in $\mathrm{THF} / \mathrm{Bu}_{4} \mathrm{NPF}_{6}$ as the electrolyte. Such behavior is typical of a weakly interacting system. Effects like solvent reorganization and increasing Coloumbic repulsion upon adding further positive charges are likely similar for all compounds. We therefore assign the observed wave broadening to weak electronic interactions between the individual ferrocenyl sites in 9. These are presumably transmitted by the ethynyl spacers and transanular or through bond interactions within the four-membered $(\mathrm{Al}-\mathrm{C} \equiv \mathrm{CFc})_{2}\left(\mathrm{CCH}_{2} \mathrm{Ph}\right)_{2}$ rings. From the broadening of the wave and after accounting for Ohmic drop the half wave potentials of the individual ferrocenyl entities were determined. This was done under the premise that there are two independent pairs of weakly interacting ferrocene sites with no interaction between the two $(\mathrm{Al}-\mathrm{C} \equiv \mathrm{CFc})_{2}\left(\mathrm{CCH}_{2} \mathrm{Ph}\right)_{2}$ entities of 9. The individual redox potentials were then assessed by digital simulation. A satisfactory fit over the range of sweep rates employed in this study $(0.051 \mathrm{~V} / \mathrm{s})$ was obtained by assuming a $65 \mathrm{mV}$ difference between the individual half wave potentials (see Table 1).

\section{Acknowledgement}

This work was supported by the Deutsche Forschungsgemeinschaft and the Göttinger Akademie der Wissenschaften.

\section{References}

[1] G.R. Newkome, E. He, C.N. Moorefield, Chem. Rev. 99 (1999) 1689.

[2] P. Nguyen, P.G. Elipe, I. Manners, Chem. Rev. 99 (1999) 1515.

[3] J.B. Flanagan, S. Margel, A.J. Bard, F.C. Anson, J. Am. Chem. Soc. 100 (1978) 4248.

[4] D. Astruc, New J. Chem. 16 (1992) 305.

[5] C. Valérion, J. L. Fillaut, J. Ruiz, J. Guittard, J. C. Blais, D. Astruc, J. Am. Chem. Soc. 119 (1997) 2588

[6] A.J. Bard, Nature 374 (1995) 13.

[7] P.D. Beer, Acc. Chem. Res. 31 (1998) 71. 
[8] D. Astruc, Acc. Chem. Res. 33 (2000) 287.

[9] K. Takada, D.J. Díaz, H.D. Abruna, I. Cuadrado, C. Casado, B. Alonso, M. Morán, J. Losaad, J. Am. Chem. Soc. 119 (1997) 10763.

[10] F. Maury, L. Brandt, H.D. Kaesz, J. Organomet. Chem. 449 (1993) 159.

[11] H.D. Kaesz, R.S. Williams, R.F. Hicks, J.I. Zink, Y. J. Chen, H. J. Muller, Z. Xue, D. Xu, D.K. Shuh, Y.K. Kim, New J. Chem. 14 (1990) 527.

[12] S.S. Kumar, N.D. Reddy, H.W. Roesky, D. Vidovic, J. Magull, R.F. Winter, Organometallics 22 (2003) 3348.

[13] S.S. Kumar, J. Rong, S. Singh, H.W. Roesky, D. Vidovic, J. Magull, D. Neculai, V. Chandrasekhar, M. Baldus, Organomet allics 23 (2004) 3496.

[14] N.D. Reddy, S.S. Kumar, H.W. Roesky, D. Vidovic, J. Magull, M. Noltemeyer, H. G. Schmidt, Eur. J. Inorg. Chem. (2003) 442.

[15] S.S. Kumar, H.W. Roesky, Dalton Trans. (2004) 3927.
[16] N.D. Reddy, H.W. Roesky, M. Noltemeyer, H. G. Schmidt, Inorg. Chem. 41 (2002) 2374.

[17] W.J. Zheng, H.W. Roesky, J. Chem. Soc., Dalton Trans. (2002) 2787.

[18] A. Stasch, M. Ferbinteanu, J. Prust, W. Zheng, F. Cimpoesu, H.W. Roesky, J. Magull, H. G. Schmidt, M. Noltemeyer, J. Am. Chem. Soc. 124 (2002) 5441

[19] G.D. Broadhead, J.M. Osgerby, P.L. Pauson, J. Chem. Soc. (1958) 650.

[20] M. Rosenblum, N. Brawn, J. Papenmeier, M. Applebaum, J. Organomet. Chem. 6 (1966) 173.

[21] T.S. Abram, W.E. Watts, Syn. React. Inorg. Met Org. Chem. 6 (1976) 31.

[22] J.W. Hershberger, R.J. Klingler, J.K. Kochi, J. Am. Chem. Soc. 105 (1983) 61.

[23] R.S. Nicholson, I. Shain, Anal. Chem. 36 (1964) 706. 